\title{
HIV-blood scientist defends reporting delay
}

Washington. A consultant virologist hired by a US manufacturer of HIV-infected blood products has defended himself against criticism for not going public sooner with the results of research carried out in 1985 showing the potential inadequacy of the company's heat treatment for killing the virus.

At least six haemophiliac children became infected with HIV after the company, Armour Pharmaceutical - now a subsidiary of Rhône Poulenc Rorer - one of the top five blood products companies in the US, continued to market its blood clotting product, Factorate, in Canada for two years, despite research showing that not all traces of HIV were destroyed by its heat treatment.

The research had been conducted by Alfred Prince, head of the laboratory of virology and parasitology at the New York Blood Center. Prince argues that Armour's decisions not to withdraw the product, nor to inform the Food and Drug Adminstration (FDA) immediately of his results, were justified in the light of uncertainty at the time about HIV.

Prince denies that the company was motivated by a desire to maintain sales in the face of stiff competition. "Actions taken then cannot be judged in the light of our knowledge today," he says, adding that, as the process of removing Factor VIII from plasma involves a number of steps which could remove or activate the virus, "we pointed out at the time that the relatively modest virus inactivation resulting from the Armour heating process did not necessarily imply that their actual product was unsafe".

But haemophiliacs in both the United States and Canada claim that company documents made public for the first time last month suggest Armour was also motivated by a desire to avoid the delays and extra investment needed to introduce an extended heat treatment.

"They had virus [in the product] and Prince knew it; that is not a grey area," says Corey Dubin, vice-president of the USbased Committee of 10,000 , an activist group of haemophiliacs infected with HIV, and a member of the FDA's Advisory Committee. Dubin claims that by 1985 , it was well-known that HIV infection was transmitted by blood, and that contact could lead to AIDS.

Over half of 16,000 haemophiliacs in the United States have become infected with HIV through contaminated blood products, and three hundred have sued Armour. Up to now, the documents surrounding the suits have been sealed by US courts. But the Canadian action means that they have been made public for the first time.

The documents reveal that an active debate took place within the company then owned by Revlon Health Care - following Prince's conclusions that only 70 per cent of virus added to blood products was killed by Armour's method of heating its blood products, which involved keeping them at $60^{\circ} \mathrm{C}$ for 30 hours.

Despite the indication that not all the virus had been killed, Armour officials felt that Prince's results were insufficient to halt distribution of Factorate, given that the FDA had approved the heat treatment method and the product itself the previous year. "We could only say that the process was not strong, not that the process was unsafe," Prince said.

But the report of an internal company meeting indicates that company executives were also reluctant to commit themselves to the extra investment needed to introduce a more costly process of heat-treating the product, used by its major competitors, keeping it at $68^{\circ} \mathrm{C}$ for 72 hours.

The minutes of Revlon's Recombinant DNA Steering Committee, held on 15 October 1985, reveals several executives arguing against informing the FDA of the preliminary results of studies showing that "detectable levels" of HIV remained after heat treatment. Some stressed the need to remain competitive in the face of "bids coming up in Canada and France".

The minutes of the meeting also appear to confirm Prince's complaint that he wanted to publish his results, but was prevented at the time from doing so by Armour, one of whose executives agreed to "review the relevant agreement with Prince to ensure publication does not violate our proprietary data rights".

Prince subsequently repeated the experi- ments independently, and published the result in The Lancet in 1986 (1: 1280, 1986). In a statement issued last month, Prince says that "as Armour had previously been informed by the Centers for Disease Control and Prevention (CDC) and the FDA that their process was highly effective, our data were understandably greeted with initial scepticism."

Despite the results of Prince's study, Armour proceeded with its plans to sell Factorate to the Canadian government's health system. In January 1987, apparently in response to growing concerns, the company began selling higher heat-treated Factorate in January 1987. But its distribution of the lower heat-treated product was not halted in Canada until November 1987.

Some critics, such as Dubin, say that Prince should have gone directly to the FDA, and been more vocal about his results. "Whether anybody sues Prince personally is still open," says Dubin.

But Mark Feinberg, a virologist and member of a committee at the Institute of Medicine that had just completed a study of the US blood system, says that even if Prince had spoken with the FDA, the agency probably would not have informed other blood products companies and the public of the research results, in order to protect Armour's proprietary interests.

Harold Sox, chair of both the department of medicine at Dartmouth Medical School and the Institute of Medicine panel, suggests the FDA would not have withdrawn the product in the belief that "companies would not knowingly distribute product infected with HIV".

Adrianne Appel

\section{Accidental contamination 'unlikely'}

Washington. The US Nuclear Regulatory Commission (NRC) says accidental contamination is unlikely to have been the cause of an incident at the Massachusetts Institute of Technology (MIT) in August in which a postdoctoral researcher ingested a large dose of radioactive phosphorus-32 (see Nature 377, 563; 1995).

At a meeting held to close the first stage of the commission's investigation of the incident, John Glenn, an NRC inspector, is said to have told David Litster, MIT's vice-president for research, that no evidence had been found of an accidental spill of the radioactive tracer.

But Glenn said he could not entirely rule out an accident. According to Victor Dricks, a spokesman for the NRC, a team from the commission's Office of Investigation will continue to investigate the circumstances in which the radioac- tive material was ingested.

The NRC also reported the discovery of "some problems with the security" of radioactive elements at the laboratory of Susumu Tonegawa, where the incident took place. Ken Campbell, a spokesman for MIT, said that the main problem encountered by inspectors was the use of a chair to hold open permanently a door that the law requires to be locked.

The NRC is now preparing its own estimate of the amount of phosphorus32 ingested by the researcher, Yuqing Li. MIT officials say that the dose was 579 microcuries - just below the 600 microcuries that would have required it to notify the commission when the incident took place. MIT notified the NCR on 16 October, when reports were about to surface in the press. A third estimate is being prepared independently at Li's request.

Colin Macilwain 